\title{
Sistem pendukung keputusan pemilihan supplier cosmetic dengan metode weighted product
}

\author{
Maha Rani ${ }^{1}$, Ricki Ardiansyah ${ }^{\left.1^{*}\right)}$, Dian Christina ${ }^{1}$ \\ ${ }^{1}$ Universitas Putra Indonesia "YPTK" Padang, Indonesia
}

\section{Article Info \\ Article history: \\ Received Apr $11^{\text {th }}, 2021$ \\ Revised May $03^{\text {rd }}, 2021$ \\ Accepted Jun $15^{\text {th }}, 2021$}

\section{Keyword:}

Pemilihan supplier

SPK

WP

\begin{abstract}
Penelitian ini dilakukan untuk membangun sebuah sistem penunjang keputusan yang dapat digunakan oleh toko Al-Fazza Cosmetic untuk memberikan rekomendasi dalam pemilihan supplier. Dalam membangun sistem penunjang keputusan ini penulis menggunakan metode weighted product (wp) untuk melakukan pengolahan data dan melakukan perangkingan alternatif yang akan digunakan sebagai hasil rekomendasi dari sistem penunjang keputusan ini. Metode weighted product (wp) adalah metode yang melakukan perkalian terhadap semua bobot alternatif yang sebelumnya sudah dipangkatkan dengan bobot dari kriteria yang sudah dinormalisasikan. Dalam melakukan pemilihan supplier di toko Al-Fazza Cosmetic kriteria yang dijadikan acuan oleh pembuat keputusan yaitu kelengkapan barang, lama kadaluarsa, harga rata-rata, jarak supplier, dan akses transportasi dengan masing-masing bobot kriteria $(5,4,3,2,1)$. Dari hasil analisa dan pengolahan data yang didapat dengan menggunakan metode weighted product (wp) sistem penunjang keputusan yang dibangun dapat memberikan perangkingan terhadap alternatif dan memberikan rekomendasi kepada pembuat keputusan di toko al_fazza cosmetic dalam memilih supplier. Hasil rekomendasi yang diberikan sistem penunjang keputusan ini bukan merupakan hasil akhir ataupun keputusan mutlak yang harus diambil, melainkan rekomendasi yang dapat digunakan pembuat keputusan dalam menentukan keputusannya.
\end{abstract}

(C) 2021 The Authors. Published by IICET.

This is an open access article under the CC BY-NC-SA license

(https://creativecommons.org/licenses/by-nc-sa/4.0)

\section{Corresponding Author:}

Ricki Ardiansyah,

Universitas Putra Indonesia "YPTK" Padang

Email: ricki.a0112@gmail.com

\section{Pendahuluan}

Salah satu yang berperan penting dalam aktivitas usaha seperti toko Al-Fazza Cosmetic yaitu adanya supplier yang mensuplai barang. Peran supplier menjadi penting untuk menjaga agar aktivitas toko tetap dapat berjalan dan barang-barang tetap tersedia. Namun masalah terjadi saat ingin menentukan supplier yang sesuai dengan kriteria yang diinginkan (Hutagalung, 2019; Mukmin et al., 2018).

Seleksi supplier mempunyai peranan yang sangat penting dalam aktivitas usaha toko. Kesalahan dalam memilih supplier dapat mempengaruhi aktivitas toko karena pilihan supplier mempengaruhi ketersediaan barang, kwalitas, harga, dan kepuasan konsumen. Pemilihan supplier yang tepat dapat menjamin keberlangsungan aktivitas usaha pada toko Al-Fazza Cosmetic dan menjaga hubungan kerjasama antara supplier dan toko dalam jangka panjang (Handayani, 2015; Ma'mur \& Maulina, 2020). 
Sistem penunjang keputusan adalah sistem berbasis pengetahuan yang dipakai untuk mengambil keputusan dalam organisasi atau perusahaan (Amalia et al., 2017). Sistem penunjang keputusan menggunakan preferensi dari pembuat keputusan dalam memilih alternatif yang tersedia berdasarkan nilai dan kriteriakriteria dari pembuat keputusan dalam menentukan alternatif terbaik (Dyah et al., 2018; Obert \& Fadlan, 2018; Yoni \& Mustafidah, 2016). Peneltian SPK yang sudah pernah dilakukan sebelumnya yaitu, SPK pemilihan alat musik pada studio music (Fauzi, 2018), SPK anlisa pemilihan handphone (Putra et al., 2018), SPK Pemilihan sepatu keselamatan (Amalia et al., 2017), SPK pemilihan pembuat kerudung (Prasetyo, 2017), SPK pemilihan karyawan terbaik (Ramadhan \& Santika, 2020).

Pada penelitian ini untuk mendapatkan supplier terbaik maka dilakukan analisa dan perhitungan terhadap kriteria-kriteria/atribut yang ada pada alternatif dengan menggunakan metode Weighted Product (WP) (T. Hidayat \& Komariah, 2020; Putra et al., 2018; Sambani et al., 2016). Metode Weighted Product merupakan salah satu metode yang populer dalam menyelesaikan kasus pengambilan keputusan multi kriteria. Metode Weighted Product ini dipilih karena kemampuannya dalam memberikan solusi yang optimal dalam menentukan peringkat dari beberapa alternatif supplier yang ada. Pemilihan metode ini juga dikarenakan kemudahan dalam melakukan perhitungannya dan tidak memerlukan waktu yang lama dalam perhitungannya (Basri, 2017; Kurniawan \& Amanda, 2017; Marpaung et al., 2018). Dalam mencari supplier terbaik di toko Al-Fazza Cosmetic menurut pembuat keputusan kriteria-kriteria yang akan menjadi bahan analisa dan perhitungan adalah kelengkapan barang, lama kadaluarsa, harga rata-rata, jarak supplier, dan akses transportasi

Rumusan masalah dalam penelitian ini adalah masih sulitnya toko Al-Fazza Cosmetic menentukan pilihan suplier terbaik dari beberapa supplier yang ada. Tujuan dari penelitian ini yaitu membangun sebuah sistem penunjang keputusan yang akan digunakan di toko Al-Fazza Cosmetic untuk menentukan alternatif terbaik dari alternatif-alternatif supplier yang ada dengan menggunakan metode wp (weighted product). Keluaran yang diharapkan dari penelitian ini adalah sebuah sistem penunjang keputusan yang dapat memberikan perangkingan dari alternatif-alternatif yang ada sehingga membatu toko Al-Fazza Cosmetic dalam menentukan supplier terbaik. Dari penelitian ini diharapkan dapat meningkatkan efisiensi dan keuntungan sehingga bermanfaat bagi toko Al-Fazza Cosmetic (M et al., 2016; Prasetyo, 2017).

\section{Metode}

Dalam melakukan penelitian ini tahap-tahap yang dilakukan oleh penulis dalam mengumpulkan data yaitu:

\section{Pengumpulan Data}

Hal-hal yang penulis lakukan dalam pengumpulan data yang akan digunakan dalam melakukan pembuatan sistem pengambilan keputusan pada toko Al-Fazza Cosmetic 1) melakukan wawancara dengan pemilik dan karyawan toko-alfazza cosmetic untum mendapatkan informasi tentang pemilihan supplier. 2) melakukan observasi terhadap tahapan-tahapan proses pemilihan supplier dan mengamati data atau dokumen yang berkaitan dalam pemilihan supplier. 3) melakukan studi pustaka yang berkaitan dengan kasus yang sedang diteliti dengan membaca contoh-contoh kasus yang sudah ada sebelumnya melalui jurnal dan buku-buku terkait. 4) mempelajari metode yang akan digunakan dalam pengambilan keputusan di toko Al-Fazza Cosmetic (Elfy Susanti, 2020).

\section{Pencarian Keputusan Dalam Metode Weighted Product (WP)}

Metode Weighted Product (WP) adalah mencari keputusan dengan cara melakukan perkalian untuk menghubungkan rating attribut, dimana attribut tersebut harus dipangkatkan dulu dengan bobot dari attribut yang bersangkutan.dalam metode wp sebelum melakukan perkalian nilai setiap attribut dilakukan normalisasi terlebih dahulu. Nilai bobot yang bersifat keuntungan (benefit) maka nilai pemangkatannya positif sedangkan yang bersifat biaya (cost) pemangkatannya negative (Amalia et al., 2017; Fitria \& Rakhmah, 2019; C. R. Hidayat et al., 2018; Marpaung et al., 2018; Putra et al., 2018).

Langkah-langkah dalam melakukan perhitungan untuk mencari alternatif terbaik dalam metode WP adalah : 1) Menentukan kriteria dan memberi nilai bobot berdasarkan kepentingan masing-masing kriteria serta menentukan sifat kriterianya; 2) Menentukan range nilai masing-masing kriteria dan memberikan nilai bobot masing-masing range nilainya; 3) Melakukan penilaian terhadap masing-masing alternatif terhadap kriteria; 4) Melakukan normalisasi bobot; 5) Mencari nilai vector s; 6) Mencari nilai vector v; 7) Melakukan perangkingan terhadap nilai vector $\mathrm{v}$ yang di dapat, nilai vector vi terbesar akan menjadi pilihan terbaik. 


\section{Pembahasan}

Dalam menentukan supplier dalam sebuah toko sering kali menjadi hal yang sulit karena banyaknya pertimbangan dan perhitungan yang harus dilakukan oleh pembuat keputusan. Untuk membuat keputusan dalam memilih supplier yang terbaik pembuat keputusan membutuhkan waktu dalam melakukan perhitungan dan pertimbangan. Supplier yang terbaik akan menambah efisiensi toko sehingga meningkatkan keuntungan yang didapat dan meningkatkan kepuasan konsumen terhadap pelayanan, kualitas dan ketersediaan barang yang ada di toko (Sambani et al., 2016).

Untuk mempermudah pembuat keputusan dalam memilih supplier terbaik, maka dibutuhkan sebuah sistem penunjang keputusan untuk membantu para pembuat keputusan di toko Al-Fazza Cosmetic. Sistem penunjang keputusan yang dibuat dapat memberikan alternatif-alternatif pilihan terbaik berdasarkan kriteriakriteria dan pertimbangan dari pembuat keputusan dengan waktu yang singkat. Alternatif-alternatif keputusan yang dihasilkan nantinya dapat digunakan oleh pembuat keputusan dalam menentukan keputusan terbaik dalam memilih supplier di toko Al-Fazza Cosmetic. Sistem penunjang keputusan ini nanti akan menggunakan metode Weighted product (wp)dalam menentukan perangkingan pada alternatif-alternatif keputusannya.

Weighted product (WP) adalah sebuah metode yang menggunakan perkalian dalam mengkorelasikan rating attribut dimana ratingnya dipangkatkan dengan bobot attribut yang bersangkutan. Proses yang digunakan sama dengan proses normalisasi. Metode Weighted product (WP) merupakan salah satu pilihan metode multi attribute decision making (MADM) yang dapat digunakan dalam menyelesaikan masalah pemilihan alternatif dengan banyak atribut (Berlilana et al., 2018; Ma'mur \& Maulina, 2020).

Multi attribute decision making (MADM) adalah metode yang digunakan untuk mencari alternatif terbaik dari beberapa alternatif yang ada berdasarkan kriteria tertentu. Dalam MADM setiap atribut diberikan nilai bobot dan dilakukan proses perangkingan untuk menyeleksi alternatif-alternatif yang ada sehingga didapat alternatif terbaik. Dalam kasus toko Al-Fazza Cosmetic kriteri-kriteria yang digunakan dalam pemilihan supplier dan bobotnya dapat dilihat pada tabel dibawah ini (T. Hidayat \& Komariah, 2020).

Tabel 1. Kriteria nilai bobot dan sifat kriteria

\begin{tabular}{clll}
\hline Kriteria & \multicolumn{1}{c}{ Keterangan } & Bobot & Sifat Benefit/Cost \\
\hline C1 & Kelengkapan Barang & 5 & Benefit \\
C2 & Lama Kadaluarsa & 4 & Benefit \\
C3 & Harga Rata Rata & 3 & Cost \\
C4 & Jarak Supplier & 2 & Cost \\
C5 & Akses Transportasi & 3 & Benefit \\
\hline
\end{tabular}

Berikut ini adalah tabel penilaian kriteria kelengkapan barang dan bobotnya.

Tabel 2. Range Nilai Kriteria Kelengkapan Barang

\begin{tabular}{llc}
\hline Kelengkapan Barang & \multicolumn{1}{c}{ Keterangan } & Bobot \\
\cline { 2 - 3 } & Sangat Lengkap & 3 \\
& Lengkap & 2 \\
& Kurang Lengkap & 1 \\
\hline
\end{tabular}

Berikut ini adalah tabel penilaian kriteria lama kadaluarsa dan bobotnya.

Tabel 3. Range Nilai Kriteria Lama Kadaluarsa

\begin{tabular}{llc}
\hline Lama Kadaluarsa & \multicolumn{1}{c}{ Keterangan } & Bobot \\
\cline { 2 - 3 } & 3 Tahun & 3 \\
& 2 Tahun & 2 \\
& 1 Tahun & 1 \\
\hline
\end{tabular}

Berikut ini adalah tabel penilaian kriteria harga rata-rata dan bobotnya.

Tabel 4. Range Nilai Kriteria Harga Rata-Rata

\begin{tabular}{llc}
\hline Harga Rata-rata & Keterangan & Bobot \\
& Mahal & 3 \\
& Murah & 2 \\
& Sangat Murah & 1 \\
\hline
\end{tabular}


Berikut ini adalah tabel penilaian kriteria jarak supplier dan bobotnya.

Tabel 5. Range Nilai Kriteria Jarak Supplier

\begin{tabular}{llc}
\hline Jarak Supplier & \multicolumn{1}{c}{ Keterangan } & Bobot \\
\cline { 2 - 3 } & Diatas $15 \mathrm{Km}$ & 3 \\
& Diatas $10 \mathrm{Km}$ & 2 \\
& Dibawah $10 \mathrm{KM}$ & 1 \\
\hline
\end{tabular}

Berikut ini adalah tabel penilaian kriteria akses transportasi dan bobotnya.

Tabel 6. Range Nilai Kriteria Akses Transportasi

\begin{tabular}{llc}
\hline Akses Transportasi & \multicolumn{1}{c}{ Keterangan } & Bobot \\
\cline { 2 - 3 } & Sangat Mudah & 3 \\
& Mudah & 2 \\
& Sulit & 1 \\
\hline
\end{tabular}

Yang terakhir adalah tabel beberapa alternatif supplier beserta penilaian yang diberikan oleh pembuat keputusan. Data dari hasil penilaian pembuat keputusan ini yang nantinya akan digunakan dalam pembuatan system penunjang keputusan untuk memilih alternative supplier terbaik dengan menggunakan metode Weighted product (WP).

Tabel 7. Alternatif dan nilainya

\begin{tabular}{cccccc}
\hline \multirow{2}{*}{ Alternatif } & \multicolumn{5}{c}{ Kriteria } \\
\cline { 2 - 5 } Toko M C A1 & Sangat Lengkap & C2 Tahun & Sangat Murah & Diatas 10 Km & Sulit \\
Toko F C A2 & Lengkap & 2 tahun & Murah & Diatas 10 Km & Mudah \\
Toko D C A3 & Kurang & 3 Tahun & Sangat Murah & Dibawah 10 & Sangat Mudah \\
& Lengkap & & Km & Mudah \\
Toko G C A4 & Kurang & 2 Tahun & Murah & Diatas 15 Km & \\
& Lengkap & & & & \\
\hline
\end{tabular}

Berdasarkan data diatas maka dilakukanlah pengolahan data dan pencarian keputusan dengan metode Weighted Product (WP). Dari perhitungan maka didapatlah nilai Vi yang akan digunakan untuk melakukan perangkingan dalam mencari supplier terbaik. Urutan nilai Vi masing-masing alternatif dari yang paling tinggi sampai yang paling rendah yaitu Alternatif 1 dengan nilai 0,2952 selanjutnya Alternatif 3 dengan nilai 0,2814 lalu Alternatif 2 dengan nilai 0,2381 dan terakhir Alternatif 4 dengan nilai 0,1852. Berdasarkan hasil perangkingan tadi maka supplier terbaik berdasarkan kriteria yang diberikan yaitu Alternatif 1 yaitu Toko Mela Cosmetic.

Dari hasil pembuatan sistem penunjang keputusan yang dilakukan, maka sistem penunjang keputusan yang dibuat dapat memberikan alternatif-alternatif pilihan yang dapat digunakan oleh pembuat keputusan dalam membuat keputusannya. Sistem penunjang keputusan yang dibuat dapat memudahkan pembuat keputusan di toko Al-Fazza Cosmetic dalam menentukan supplier terbaik yang akan dipilih dalam waktu yang singkat. Metode Weighted Product (WP) yang digunakan dapat melakukan perhitungan dan memberikan perangkingan terhadap alternatif-alternatif yang ada berdasarkan kriteria yang diberikan.

Beberapa penelitian sistem penunjang keputusan terdahulu dengan metode wp yang digunakan sebagai referensi dalam penelitian ini yaitu (Fauzi, 2018) dengan judul "Penerapan Metode Weight Product Untuk Sistem Pendukung Keputusan Pemilihan Pemasok Alat Musik Pada Studio Musik Enterprise". Dalam penelitiannya dihasilkan sebuah system penunjang keputusan yang dapat memberikan perhitungan yang akurat yang dapat digunakan dalam membantu pemilihan alat music tanpa memerlukan waktu yang lama. Metode Weighted Product yang digunakan dapat memberikan hasil yang efektif berdasarkan kriteria yang diberikan.

Selanjutnya yaitu penelitian dari (Putra et al., 2018) dengan judul "Analisis Pemilihan Handphone Rekomendasi Dengan Metode Weighted Product". Penelitian yang dilakukan dengan menggunakan metode Weight Product dapat memberikan nilai Vi yang akan digunakan dalam melakukan perangkingan terhadap 
beberapa merk handphone yang digunakan dalam memberikan rekomendasi kepada pengguna berdasarkan kriteria-kriteria yang sudah ditentukan.

Penelitian lainnya yaitu (Amalia et al., 2017) tentang "Sistem Pemilihan Supplier Sepatu Keselamatan Dengan Metode Weighted Product". Sistem penunjang keputusan yang dibangun dapat memberikan rekomendasi supplier sepatu keselamatan untuk membantu perusahaan dalam memilih suppliernya. metode Weight Product yang digunakan menghasilkan hasil yang efisien dengan perhitungan yang sederhana. Sistem yang dibangun bekerja berdasarkan bobot dan kriteria yang diberikan dan menghasilkan perangkingan supplier sepatu keselamayan.

Ada pula penelitian dari (Prasetyo, 2017) tentang "Sistem Pendukung Keputusan Menentukan Produsen Terbaik Dalam Pembuatan Kerudung Pada Cv. Hazna Indonesia Menggunakan AHP (Analytical Hierarchy Process) Dan WP (Weighted Product)". Sistem penunjang keputusan yang dibuat dapat memberikan rekomendasi produsen terbaik berdasarkan alterbatif produsen dan kriteria harga, kualitas, ketepatan kirim, dan ketepatan jumlah. Sistem penunjang keputusan yang dibuat telah memenuhi gungsi yang diinginkan sesuai dengan kebutuhan pengguna.

Lalu penelitian dari (Ramadhan \& Santika, 2020) "AHP dan WP: Metode dalam Membangun Sistem Pendukung Keputusan (SPK) Karyawan Terbaik". Sistem yang dibuat memiliki konsistensi kesalahan kurang dari $10 \%$ dan berjalan dengan baik dan sesuai kebutuhan. Sistem yang dibangun dapat memberikan pilihan alternative karyawan terbaik untuk dipilih oleh pembuat keputusan.

\section{Simpulan}

Berdasarkan dari hasil analisa dan pengolahan data serta perhitungan yang dilakukan pada bab sebelumnya maka dapat diambil beberapa kesimpulan dari penelitian yang dilakukan, kesimpulan yang dapat diambil sebagai berikut: 1) Sistem penunjang keputusan yang dibuat dapat memberikan rekomendasi kepada pembuat keputusan dalam pemilihan supplier pada toko Al-Fazza Cosmetic berdasarkan kriteria yang diberikan dari alternatif-alternatif yang ada; 2) Metode Weighted Product (WP) yang digunakan dalam sistem penunjang keputusan memberikan hasil perangkingan dari alternatif-alternatif keputusan dengan perhitungan yang sederhana; 3) Hasil yang diberikan sistem penunjang keputusan ini bukan merupakan hasil akhir atau pilihan mutlak melainkan rekomendasi yang dapat digunakan pembuat keputusan sebagai pertimbangan dalam membuat keputusan pemilihan suppliernya.

\section{Referensi}

Amalia, A., Cahyadi, D., \& Astuti, I. F. (2017). Sistem Pemilihan Supplier Sepatu Keselamatan Dengan Metode Weighted Product. Prosiding Seminar Nasional Ilmu Komputer Dan Teknologi Informasi, 2(2), 9-16.

Basri. (2017). Metode Weightd Product (Wp) Dalam Sistem Pendukung Keputusan Penerimaan Beasiswa Prestasi. Jurnal INSYPRO (Information System and Processing), 2(1), 1-6. https://doi.org/https://doi.org/10.24252/insypro.v2i1.2474.g2610

Berlilana, B., Prayoga, F. D., \& Utomo, F. S. (2018). Implementasi Simple Additive Weighting dan Weighted Product pada Sistem Pendukung Keputusan untuk Rekomendasi Penerima Beras Sejahtera. Jurnal Teknologi Informasi Dan Ilmu Komputer, 5(4), 419. https://doi.org/10.25126/jtiik.201854768

Dyah, D., Wiyono, S., \& Mahardhika, S. (2018). Penerapan Metode Weighted Product Untuk Sistem Pendukung Keputusan Penerima Beasiswa Politeknik Harapan Bersama Tegal. Jurnal Informatika: Jurnal Pengembangan IT, 3(2), 136-142. https://doi.org/10.30591/jpit.v3i2.902

Elfy Susanti, R. (2020). Analytical, Metode Process, Hierarchy Dan, A H P Saw, Additive Weighting Pada apotek pusaka arta dengan metode. Jurnal I D E A L I S, 3, 405-410.

Fauzi, M. (2018). Penerapan Metode Weight Product Untuk Sistem Pendukung Keputusan Pemilihan Pemasok Alat Musik Pada Studio Musik Enterprise. Jurnal Teknik Informatika Kaputama, 2(1), 98-104.

Fitria, R., \& Rakhmah, S. N. (2019). Penerapan Metode Weighted Product Untuk Menganalisis Faktor Pemilihan Pembayaran Digital Transaction Pada Aplikasi Ojek Online. Jurnal Teknika, 11(2), 1098. https://doi.org/10.30736/jt.v11i2.346

Handayani, D. I. (2015). Seleksi suplier bahan baku dengan pendekatan multi attribut decision making. Jurnal PASTI, IX(2), 149-163. https://publikasi.mercubuana.ac.id/index.php/pasti/article/download/479/420

Hidayat, C. R., Mufizar, T., \& Ramdani, M. D. (2018). Implementasi Metode Weighted Product Pada Sistem Pendukung Keputusan Seleksi Calon Karyawan Bpjs Kesehatan Tasikmalaya. Konferensi Nasional Sistem Informasi 2018, September, 530-541.

Hidayat, T., \& Komariah, S. (2020). Pemilihan Siswa-Siswi Berprestasi Menggunakan Metode Weighted 
Product (WP) Studi Kasus SMP-Al Fitroh Tangerang. Jurnal Teknik Informatika Unis, 7(2), 159-163. https://doi.org/10.33592/jutis.v7i2.398

Hutagalung, J. (2019). Studi Kelayakan Pemilihan Supplier Perlengkapan Dan ATK Menggunakan Metode SAW (Simple Additive Weighting). J-SAKTI (Jurnal Sains Komputer Dan Informatika), 3(2), 356. https://doi.org/10.30645/j-sakti.v3i2.154

Kurniawan, D. E., \& Amanda, S. T. (2017). Pemilihan Rumah Menggunakan Metode Weight Product Dengan Visualisasi Lokasi Objek. Klik - Kumpulan Jurnal Ilmu Komputer, 4(1), 102. https://doi.org/10.20527/klik.v4i1.77

M, J. E., Andreswari, D., \& Anggriani, K. (2016). Pemilihan Jenis Kayu Untuk Mebel Dengan Metode Weighted Product ( Wp ) \& Technique for Order Preference By Similarity To Ideal Solution ( Topsis ). Jurnal Rekursif, 4(3), 301-310.

Ma'mur, K., \& Maulina, B. (2020). Sistem Penunjang Keputusan Pemilihan Mekanik Terbaik Menggunakan Metode Weighted Product pada PT. Paramita Banindo. JOAIIA: Journal of Artificial ..., 1(4), 169-176. http://openjournal.unpam.ac.id/index.php/JOAIIA/article/view/7809

Marpaung, N., Handayani, M., \& Yesputra, R. (2018). Sistem Pendukung Keputusan Pemilihan Dosen Terbaik Dengan Metode Weighted Product (WP) Pada STMIK Royal. Seminar Nasional Royal 2018, 9986(September), 267-270.

Mukmin, M., Nur, J., \& Israwan, F. (2018). Sistem Pendukung Keputusan Untuk Penentuan Mahasiswa Berprestasi Menggunakan Weighted Product (Wp). Jurnal Informatika, 9.

Obert, O., \& Fadlan, M. (2018). A Comparative Study of Problem Solving Methods in Decision Support Systems. Conference SENATIK STT Adisutiipto Yogyakarta, 4. https://doi.org/10.28989/senatik.v4i0.142

Prasetyo, H. A. (2017). Sistem Pendukung Keputusan Menentukan Produsen Terbaik Dalam Pembuatan Kerudung Pada CV. Hazna Indonesia Menggunakan AHP (Analytical Hierarchy Process) dan WP (Weighted Product). Semnasteknomedia Online, 5, 13-18.

Putra, G. M., Irawati, N., Informasi, S., \& Royal, S. (2018). Analisis Pemilihan Handphone Rekomendasi Dengan Metode Weighted Product. Seminar Nasional Royal (SENAR) 2018, 9986(September), 199-204.

Ramadhan, A. G., \& Santika, R. R. (2020). AHP dan WP: Metode dalam Membangun Sistem Pendukung Keputusan (SPK) Karyawan Terbaik. Edumatic: Jurnal Pendidikan Informatika, 4(1), 141-150. https://doi.org/10.29408/edumatic.v4i1.2163

Sambani, E. B., Agustin, Y. H., \& Marlina, R. (2016). PLAZA ASIA DENGAN MENGGUNAKAN METODE WEIGHTED PRODUCT A decision support system for the promotion of Employee in Plaza Asia Method Using Weighted Product. CSRID Journal, 8(2), 121-130.

Yoni, D. C., \& Mustafidah, H. (2016). 93123-ID-penerapan-metode-wp-weighted-product-unt.pdf. IV, 22-27. 